\title{
Circulating tumor DNA to monitor metastatic breast cancer.
}

\author{
Massimo Cristofanilli \\ Kimmel Cancer Center, Thomas Jefferson University, Massimo.Cristofanilli@jefferson.edu \\ Paolo Fortina \\ Kimmel Cancer Center, Thomas Jefferson University, paolo.fortina@jefferson.edu
}

Follow this and additional works at: https://jdc.jefferson.edu/kimmelccfp

Part of the Oncology Commons

Let us know how access to this document benefits you

\section{Recommended Citation}

Cristofanilli, Massimo and Fortina, Paolo, "Circulating tumor DNA to monitor metastatic breast cancer." (2013). Kimmel Cancer Center Faculty Papers. Paper 27.

https://jdc.jefferson.edu/kimmelccfp/27

This Article is brought to you for free and open access by the Jefferson Digital Commons. The Jefferson Digital Commons is a service of Thomas Jefferson University's Center for Teaching and Learning (CTL). The Commons is a showcase for Jefferson books and journals, peer-reviewed scholarly publications, unique historical collections from the University archives, and teaching tools. The Jefferson Digital Commons allows researchers and interested readers anywhere in the world to learn about and keep up to date with Jefferson scholarship. This article has been accepted for inclusion in Kimmel Cancer Center Faculty Papers by an authorized administrator of the Jefferson Digital Commons. For more information, please contact: JeffersonDigitalCommons@jefferson.edu. 
Since publication of their article, the authors report no further potential conflict of interest.

1. Serena J, Marti-Fàbregas J, Santamarina E, et al. Recurrent stroke and massive right-to-left shunt: results from the prospective Spanish multicenter (CODICIA) study. Stroke 2008;39:3131-6.
2. Weimar C, Holle DN, Benemann J, et al. Current management and risk of recurrent stroke in cerebrovascular patients with right-to-left cardiac shunt. Cerebrovasc Dis 2009;28:34956.

DOI: 10.1056/NEJMc1305429

\section{Circulating Tumor DNA to Monitor Metastatic Breast Cancer}

TO THE EDITOR: Dawson et al. (March 28 issue ${ }^{1}$ suggest that the detection of circulating tumor DNA in $58 \%$ of patients with metastatic breast cancer can be used as an effective indicator of tumor load during treatment with standard systemic therapies. The study does not address the clinical utility of circulating tumor DNA. Moreover, the authors claim that circulating tumor DNA represents a more effective monitoring tool than the enumeration of circulating tumor cells. This statement is incorrect, considering that the enumeration of circulating tumor cells proved the ability to predict prognosis and monitor treatment efficacy in all patients with metastatic breast cancer, regardless of disease subtype. ${ }^{2}$ Furthermore, new detection methods describe the molecular heterogeneity and measure dynamic phenotypic changes in circulating tumor cells during metastasis. ${ }^{3,4}$ We propose that circulating tumor DNA provides a complementary method in the assessment of patients with detectable mutations and should be more appropriately used to select and monitor molecularly targeted therapies. Combined diagnostic methods will provide a more effective approach than each method alone to the implementation of precision medicine and improved clinical outcomes.

Massimo Cristofanilli, M.D.

Paolo Fortina, Ph.D.

Kimmel Cancer Center

Philadelphia, PA

massimo.cristofanilli@jefferson.edu

No potential conflict of interest relevant to this letter was reported.

1. Dawson S-J, Tsui DWY, Murtaza M, et al. Analysis of circulating tumor DNA to monitor metastatic breast cancer. $\mathrm{N} \mathrm{Engl} \mathrm{J}$ Med 2013;368:1199-209.

2. Cristofanilli M, Budd GT, Ellis MJ, et al. Circulating tumor cells, disease progression, and survival in metastatic breast cancer. N Engl J Med 2004;351:781-91.

3. Magbanua MJ, Sosa EV, Roy R, et al. Genomic profiling of isolated circulating tumor cells from metastatic breast cancer patients. Cancer Res 2013;73:30-40.

4. Yu M, Bardia A, Wittner BS, et al. Circulating breast tumor cells exhibit dynamic changes in epithelial and mesenchymal composition. Science 2013;339:580-4.

DOI: 10.1056/NEJMc1306040
TO THE EDITOR: Dawson et al. propose circulating tumor DNA as a new biomarker for metastatic breast cancer. In our opinion, the timing of the analysis is crucial for the correct interpretation of such data obtained from samples acquired during chemotherapy.

Apoptosis leads to the augmented release of cell-free DNA, ${ }^{1}$ so chemotherapy is expected to temporarily increase the levels of circulating tumor DNA. Thus, the assumption that such increases reflect tumor load may be incorrect, depending on the time point chosen.

We suggest a dual role for analysis with circulating tumor DNA. First, the difference between basal levels before and peak levels after the administration of chemotherapy may serve as an indicator of tumor responsiveness. Second, levels of circulating tumor DNA measured several days after the last chemotherapy cycle may serve as a surrogate marker for total tumor mass.

Analysis of the kinetics of circulating tumor DNA during the use of various chemotherapeutic drugs and regimens may pave the way for the clinical translation of analysis with circulating tumor DNA. Lukas Weiss, M.D., Ph.D.
Clemens Hufnagl, M.Sc.
Richard Greil, M.D.
Paracelsus Medical University
Salzburg, Austria
r.greil@salk.at
$\quad$ No potential conflict of interest relevant to this letter was re-
ported.

1. Schwarzenbach H, Hoon DS, Pantel K. Cell-free nucleic acids as biomarkers in cancer patients. Nat Rev Cancer 2011;11:42637.

DOI: $10.1056 / \mathrm{NEJMc1306040}$

THE AUTHORS REPLY: We support the idea that combined methods involving circulating tumor cells and circulating tumor DNA could be used to analyze tumor status and changes. By the criterion of sensitivity for detection of disease burden, our data clearly show an advantage to the 
detection of circulating tumor DNA over the enumeration of circulating tumor cells by means of the CellSearch System. Our findings provide the rationale for future studies to address the full clinical utility of analyses with circulating tumor DNA.

One apparent limitation of our work was that only two genes (PIK3CA and TP53) were analyzed for most patients. These are the two most commonly mutated genes in breast cancer, and as expected, they were informative in half the patients recruited. This does not represent a general limitation of circulating tumor DNA: as a proof of principle, we also found that we were able to monitor other somatic mutations and structural variants in a subset of patients who did not have mutations in PIK3CA or TP53. Our data indicate that any cancer-specific mutation can be monitored in circulating tumor DNA from patients with metastatic breast cancer.
The timing of blood and plasma collection is obviously an important variable. In our study, all samples were collected immediately before the administration of each treatment cycle. The possibility of measuring an increase in the release of circulating tumor DNA as an indicator of responsiveness is attractive and is supported by xenograft models. ${ }^{1}$

\section{Sarah-Jane Dawson, Ph.D. \\ Nitzan Rosenfeld, Ph.D. \\ Carlos Caldas, M.D.}

Cancer Research UK Cambridge Institute

Cambridge, United Kingdom

carlos.caldas@cruk.cam.ac.uk

Since publication of their article, the authors report no further potential conflict of interest.

1. Rago C, Huso DL, Diehl F, et al. Serial assessment of human tumor burdens in mice by the analysis of circulating DNA. Cancer Res 2007;67:9364-70.

DOI: $10.1056 / N E J M c 1306040$

\section{Globalization, Climate Change, and Human Health}

TO THE EDITOR: The scholarly review of globalization and climate change by McMichael (April 4 issue $^{1}$ emphasizes the associated economic, social, demographic, and environmental threats to human health and suggests steps to mitigate these changes on a global scale. Although McMichael also mentions the effects of climate change and globalization on the geographic range of vectorborne infections, he does not alert readers to sobering examples of the emergence of tropical infections in the temperate zone (Table 1). Globalization and climate change promote the emergence of these infections synergistically. Globalization increases the number of infected travelers and the accidental importation of infected vectors. Climate change warms the environment to temperatures that permit reproduction of the vector and parasite. Increasing

\begin{tabular}{|c|c|c|c|}
\hline $\begin{array}{l}\text { Tropical } \\
\text { Infection }\end{array}$ & Areas of Local Transmission & Comment & Reference \\
\hline Dengue & $\begin{array}{l}\text { Key West and elsewhere in Florida; } \\
\text { Brownsville, Texas; France; and } \\
\text { Croatia and other areas of } \\
\text { southern Europe }\end{array}$ & $\begin{array}{l}\text { A total of } 5 \% \text { of Key West residents } \\
\text { have antibodies against dengue, } \\
\text { and locally transmitted infections } \\
\text { have been reported in other } \\
\text { counties, including Miami-Dade; } \\
39 \% \text { of residents in Brownsville } \\
\text { have antibodies against dengue }\end{array}$ & $\begin{array}{l}\text { Jordan et al., }{ }^{2} \\
\text { Ramos et al., }{ }^{3} \\
\text { Butler }\end{array}$ \\
\hline Malaria & Greece & $\begin{array}{l}\text { The CDC recommends precautions } \\
\text { (level l) for persons who travel to } \\
\text { Greece, including consideration of } \\
\text { drug prophylaxis for travel to some } \\
\text { regions }\end{array}$ & $\mathrm{CDC}^{5}$ \\
\hline Chikungunya & Italy and France & $\begin{array}{l}\text { Hundreds of persons have been } \\
\text { infected in Italy }\end{array}$ & Butler $^{4}$ \\
\hline
\end{tabular}

* CDC denotes Centers for Disease Control and Prevention. 